\title{
A note on the influence of microgravity on the microbial endoecosystem of Japanese quail
}

\author{
Andrea Lauková ${ }^{1}$, K. Boda ${ }^{2}$ and V. Kmet'1 \\ 'Institute of Animal Physiology, Slovak Academy of Sciences, \\ ${ }^{2}$ Institute of Animal Genetics and Biochemistry, Slovak Academy of Sciences \\ Hlinkova 1/B, 040-01 Košice, Slovak Republic
}

(Received 12 November 1992; accepted 23 February 1993)

KEY WORDS: Japanese quail, microbial endoecosystem, microgravity

\section{INTRODUCTION}

Japanese quail are commercially farmed for meat and eggs in Southern Europe, Asia and India. Due to small size, low husbandry costs, short generation interval and adaptability to a wide range of husbandry conditions they are also popular laboratory animals. The Japanese quail has also become an object for space research (Boda, 1979) because it may help to solve dietary problems connected with space flight. Recently, the effect of microgravity on endocrine functions and adaptation processes (Jurani et al., 1988), embryonic development (Boda et al., 1991) and productivity of Japanese quail was studied. The present work extends this research to the microbial endoecosystem and its biochemical and physiological properties after exposition of birds to 7 days of microgravity on board of the orbital station. This study may contribute some information on the microbial status of Japanese quail under space flight conditions and help to select bacteria which could prevent microbial dysfunction of the digestive tract during flight.

\section{MATERIAL AND METHODS}

\section{Experimental procedure}

The experiment lasting 9 days was carried out on twelve Japanese quails aged 15 days divided into three groups of 4 birds each. The birds in the flight group were sent into space on board of the orbital space station MIR. The birds in the 
synchronous group were kept under simulated flight conditions. All the birds were fed the same standard pelleted diet. The quails from the flight group were killed after landing on Earth, quails from both synchronous and control groups were killed in the laboratory. Crop and caecum contents were sampled from each bird, mixed with a glycerin-phosphate buffer (1:1) and frozen on dry ice until further processing.

\section{Bacterial strains}

Staphylococci were determined on the selective medium, mannitol salt agar (Oxoid), lactabacilli on the rogosa agar (Oxoid). To isolate enterobacteriacae, Mac Conkey Agar (Imuna, Sarisske Michalany) was used. Enterococci were isolated on azide blood agar base medium (Imuna, S. Michalany) and streptococci on standard medium with addition of $20 \mathrm{~g}$ of starch. To test isolates nutrient broth and agar No. 2 (Imuna, S. Michalany), Todd-Hewitt broth and agar (Imuna) and blood agar base (Imuna) were used. The strains were determined using commercial identificational Staphy or Strepto tests (Lachema, Brno).

\section{Resistance to antibiotics}

Resistance to six antibiotics was studied using commercial Sensi-La-Disks (Lachema, Brno). Agar plates with disks were incubated at $37^{\circ} \mathrm{C}$ according to the

TABLE 1

Production of bacteriocin-like substances by tested strains

\begin{tabular}{|c|c|c|c|c|c|}
\hline \multirow{2}{*}{ Strain } & \multicolumn{5}{|c|}{ Zone of inhibition (in mm) } \\
\hline & EG 12 & EGIO & EA7 & SG2 & SA7 \\
\hline Ent. faecium EF1 & ++ & - & - & - & ++ \\
\hline Ent. faecium EFP6 & + & ++ & + & ND & ND \\
\hline Str. bovis A024/85 & ++ & ++ & + & - & - \\
\hline Str. agalactiae BM 6102 & ++ & - & - & - & - \\
\hline Staph. sp. ST20 & ++ & - & - & - & + \\
\hline Staph. aureus Oxford 209P & ++ & ++ & + & ++ & - \\
\hline Corynebact. renale CCM 5740 & ++ & - & - & - & - \\
\hline Escherichia coli $\mathrm{EC1}$ & + & + & - & - & - \\
\hline Prov. stuarti JH1 & ++ & ++ & ++ & - & - \\
\hline \multicolumn{6}{|c|}{$\begin{aligned}+ & \text { zone of inhibition imm., } \\
+ & + \text { zone of inhibition }(1-10 \mathrm{~mm}) \\
- & \text { no zone } \\
\text { ND } & \text { not determined }\end{aligned}$} \\
\hline
\end{tabular}


manufacturer's instructions. The standard strain, Staphylococcus aureus ATCC 6538 , was incubated simultaneously as a control. Disks contained the following antibiotics: strepromycin, tetracycline and chloramphenicol ( $30 \mu \mathrm{g}$ per disk), erythromycin (10 $\mu \mathrm{g}$ per disk), ampicillin ( $20 \mu \mathrm{g}$ per disk), and penicillin (10 IU per disk).

\section{Determination of bacteriocin-like substances}

Production of bacteriocin-like substances was studied according to Skalka et al. (1985). The indicator bacteria strains used in the experiment are presented in Table 1. Staphylococcus aureus CB 44 (Veterinary University, Brno) was as the positive control.

\section{Lactic acid production}

The quantity of lactic acid produced, expressed in mol. $\mathrm{L}^{-1}$, was examined using the precipitation method as described by Pryce et al. (1969).

Urease activity (E.C. 3.5.1.5.) was measured by a spectrophotometric method according to Cook (1976) and expressed in nkatm ${ }^{-1}$.

Total bacteria counts expressed as $\log 10 \pm \mathrm{SEM}$

Urease activity and lactic acid production are arithmetical averages \pm SEM.

\section{RESULTS}

The largest total counts of enterococci and enterobacteriacae were found in the caeca of Japanese quails in the flight group (Fig. 1). The total counts of lactobacilli, streptococci and staphylococci were the largest in caeca of the synchronous group. The difference between the flight and the control groups was significant $(P<0.05)$ only in respect to the enterobacteriacae count. Higher counts of enterobacteriacae, staphylococci and streptococci were found in the crop of birds from the synchronous group (Fig. 2) in comparison to the flight group. According to the identificational scheme (Buchanan and Gibbons, 1984) the strains were allotted to the species Enterococcus gallinarum (EGIO. EG12), E. avium (EA7), Staphylococcus gallinarum (SG2) and $S$. aureus (SA7). All of these strains were resistant to penicillin and strain EG10 was also resistant to streptomycin. All the strains were sensitive to all of the other antibiotics used. Bacteriocin-like substances produced by strain EG12 inhibited the growth of all bacteria species used. The antimicrobial activity of the bacteriocin-like substances produced by all the strains inhibited the growth of at least one of the nine indicators used. 


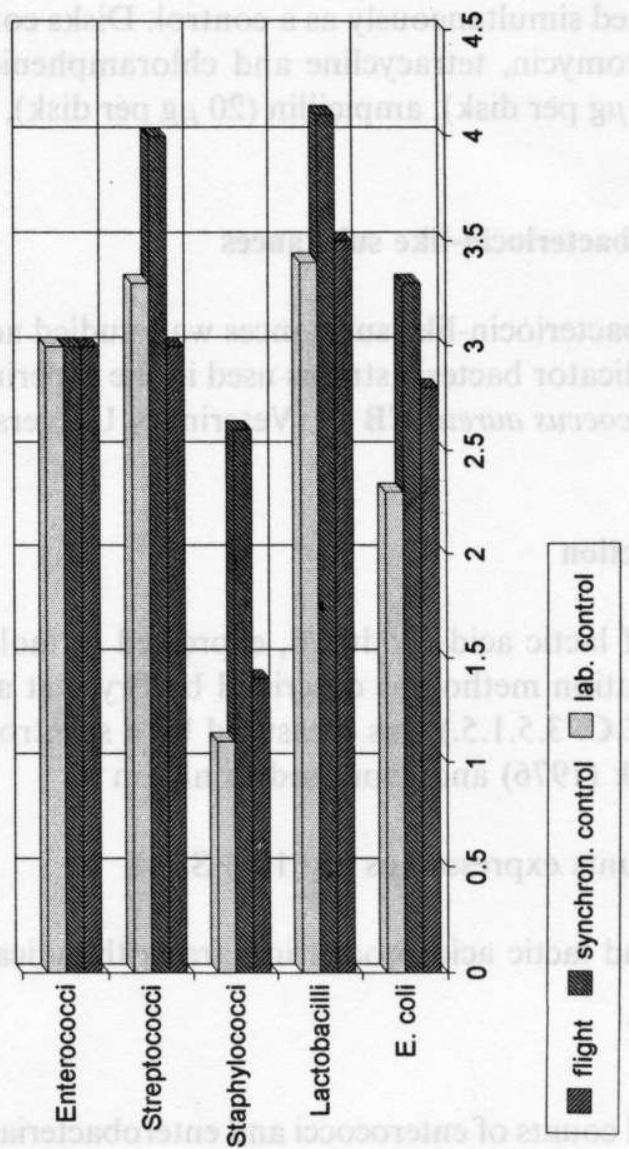

Figure 1. Total counts of bacteria isolated from caecum of Japanese Quail

The average diameter of the zone of inhibition ranged from 4 to $6 \mathrm{~mm}$ and the majority of these zones were clear (Table 1). Urease and lactic acid production ranged from 0.39 to $3.7 \mathrm{nkat} / \mathrm{mL}^{-1}$ and from 0.720 to $0.186 \mathrm{~mol} / \mathrm{L}^{-1}$, respectively (Table 2 ).

\section{DISCUSSION}

In general, the microbial population of Japanese quails was not affected by microgravitation. The occurrence of facultative anaerobic microorganisms was lower than reported by Barnes et al. (1972), Fuller (1977) and Kóniarova (1991) in the caeca and crop of chickens under normal conditions. The enterococci 
TABLE 2

Lactic acid production and urease activity of tested strains

\begin{tabular}{lccc}
\hline \multicolumn{1}{c}{ Strain } & Urease & Lactic acid \\
\hline Ent. gallinarum EG10 & $2.45 \pm 0.12$ & 0.505 \\
Ent. gallinarum EG12 & $0.39 \pm 0.02$ & 0.186 \\
Ent. avium EA7 & $2.5 \pm 0.04$ & 0.412 \\
Staph. gallinarum SG2 & $0.7 \pm 0.004$ & 0.170 \\
Staph. aureus SA7 & $3.7 \pm 0.13$ & 0.720 \\
\hline
\end{tabular}

Lactic acid $\mathrm{mol} / \mathrm{L}^{-1}$, urease $\mathrm{nkat} / \mathrm{mL}^{-1}$

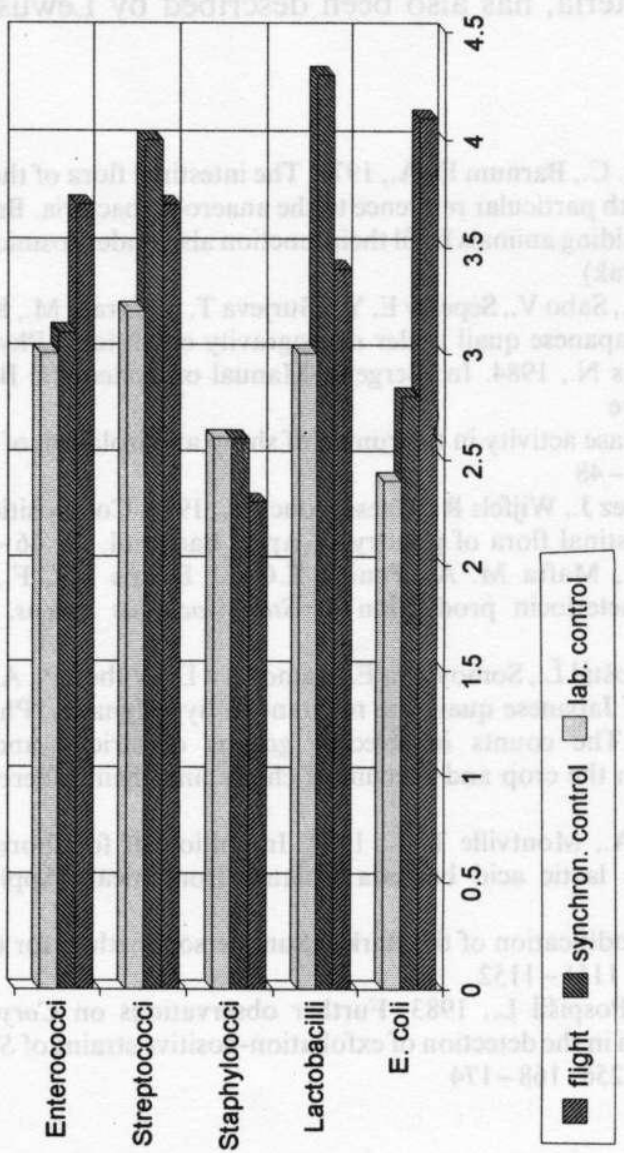

Figure 2. Total counts of bacteria isolated from the crop of Japanese quail. 
species found were the same as those described by Devriese et al. (1991) as associated with normal poultry gut flora.

The majority of the screened strains were monoresistant with the exception of strain EG10 which was resistant to two antibiotics. The strains, isolates from the crop and caecum, produced bacteriocin-like substances with a wide antimicrobial activity not only against Gram-positive, but also against Gram-negative bacteria. The strain EG12, the producer of a very active bacteriocin-like substance may be used for producing the preparation capable of adhering to the intestinal wall epithelium and supressing endogenous bacterial infections. This may be important because the normal bacterial flora present in faeces (e.g. Clostridium sp.) may multiply under the stress conditions of space flight and cause entheritis. The inhibition of pathogenic strains with bacteriocins produced by lactic acid bacteria, has also been described by Lewus et al. (1991).

\section{REFERENCES}

Barnes E. M., Mead G. C., Barnum D. A., 1972. The intestinal flora of the chicken in the period 2 to 6 weeks of age, with particular reference to the anaerobic bacteria. Br. Poultry Sci. 13,311-326

Boda K., 1979. Will yielding animals fulfil their function also under cosmic conditions? Techn. Work, $6,23-27$ (in Slovak)

Boda K., Melesko G. I.. Sabo V., Sepelev E. Y., Gurjeva T. S., Jurani M., Koślál L.. 1991. Embryonic development of Japanese quail under microgravity conditions. Physiologist, S34, 59-61

Buchanan R., Gibbons N., 1984. In: Bergey's Manual of Systematic Bacteriology. Williams and Wilkins, Baltimore

Cook A. R.. 1976. Urease activity in the rumen of sheep and isolation of ureolytic bacteria. J. Gen. Microbiol. 92, 32-48

Devriese L. A., Hommez J., Wijfels R., Haesebrouck F., 1991. Composition of the enterococcal and streptococcal intestinal flora of poultry. J. Appl. Bacteriol. 71, 46-50

Giambiagi-Marval M., Mafra M. A., Penido E.G.C., Bastos M.C.F., 1990. Distinct group of plasmids with bacteriocin production in Staphylococcus aureus. J. Gen. Microbiol. 136. $1591-1599$

Juráni M., Boda K., Koštál Ľ., Somoyiová E., Lámošová D., Výboh P., Ambruš P., Baumgartner J., 1988. Selection of Japanese quail line resistant to hypodynamy. Physiologist, S31, 140-142

Koniarová 1., 1991. The counts in selected groups of strictly and facultatively anaerobic microorganisms in the crop and caecum of chicks and their adherence characteristics. Veter. Med. 6, 349-354

Lewus C. B., Kaiser A., Montvilic T. J., 1991. Inhibition of foodborne bacterial pathogens by bacteriocins from lactic acid bacteria isolated from meat. Appl. Environ. Microbiol. 6, $1683-1688$

Pryce J. D., 1969. A modification of the Barker-Summerson method for the determination of lactic acid. Analyst, 94, 1151-1152

Skalka B., Pillich J., Pospišil L., 1983. Further observations on Corynebacterium renale as an indicator organism in the detection of exfoliation-positive strains of Staphylococcus aureus. Zbl. Bakteriol. Hyg. A256, 168-174 


\section{STRESZCZENIE}

\section{Wpływ mikrociążenia na mikroflorę przewodu pokarmowego przepiórki japońskiej}

Doświadczenie przeprowadzono na dwunastu 15-dniowych przepiórkach. podzielonych na 3 grupy: „latającą" - wysłaną w przestrzeń orbitralną, , synchroniczną" - u1rzymywaną na ziemi w warunkach symulujących lot oraz kontrolną, utrzymywaną w warunkach laboratoryjnych. Ptaki wszystkich grup otrzymywały jednakową granulowaną mieszankę. Po uboju w treści wola i jelita grubego oznaczano skład bakteryjny oraz oporność bakterii na działanie antybiotyków.

Wyizolowane szczepy należą do gatunków: Entercoccus gallinarum i avium oraz. Staphylococcus gallinarum i aureus. Stwierdzono większą liczbę enterobakterii w jelicic grubym przepiórek z grupy , latająccj" w porównaniu z pozostałymi. Wszystkie badane szczepy nie reagowały na działanie penicyliny, natomiast były wräliwe na działanie streptomycyny, tetracykliny, chloramfenikolu. erylromycyny oraz ampicyliny. Aktywność substancji przcciwbakteryjnych, wytwarzanych przez. badane szczepy, skierowana była przeciw bakteriom gram-dodatnim i gram-ujemnym. 